\title{
Toxicological screening of Mikania glomerata Spreng., Asteraceae, extract in male Wistar rats reproductive system, sperm production and testosterone level after chronic treatment
}

\author{
Rita de Cássia da Silveira e Sá, ${ }^{*, 1}$ Magda N. Leite, ${ }^{2}$ Reinaldo N. de Almeida ${ }^{3}$
}

\author{
${ }^{1}$ Centro de Biologia da Reprodução, Departamento de Biologia, Universidade Federal de Juiz de Fora, \\ Juiz de Fora-MG, Brazil,
}

${ }^{2}$ Faculdade de Farmácia e Bioquímica, Universidade Federal de Juiz de Fora, 36036-330 Juiz de Fora-MG, Brazil, ${ }^{3}$ DFP/Laboratório de Tecnologia Farmacêutica, Universidade Federal da Paraíba, 58051-970 João Pessoa-PB, Brazil.

\begin{abstract}
RESUMO: "Triagem toxocológica do extrato de Mikania glomerata Spreng., Asteraceae, no sistema reprodutor, produção espermática e nível de testosterona em machos de ratos Wistar após tratamento crônico". As plantas medicinais podem apresentar na sua constituição compostos capazes de causar efeitos adversos no organismo. Cumarina e flavonoides são substâncias encontradas em muitas espécies vegetais, cuja interferência na fertilidade de ratas e cadelas, respectivamente, foi evidenciada em estudos prévios. Mikania glomerata Spreng., Asteraceae, (guaco) é uma planta usada no tratamento de doenças respiratórias e em suas folhas foi detectada a presença de cumarina e flavonoides. Neste estudo, avaliou-se o efeito do extrato hidroalcoólico, preparado com partes aéreas de guaco, no sistema reprodutor de ratos submetidos a tratamento crônico. Ratos Wistar (trinta dias de idade) foram tratados com extrato hidroalcoólico de guaco na dose de $3,3 \mathrm{~g} / \mathrm{kg}$ de peso corporal durante noventa dias. O peso corporal e de órgãos, a produção de espermatozoides, a concentração de testosterona plasmática e o consumo de ração foram avaliados. Não foi observada nenhuma alteração significativa das variáveis analisadas e o tratamento não afetou o consumo de ração. Estes dados sugerem que, na dose utilizada, o extrato hidroalcoólico de guaco não teve efeito tóxico e nem interferiu com a fertilidade de ratos Wistar submetidos a um tratamento de longa duração.
\end{abstract}

Unitermos: Mikania glomerata, órgãos reprodutivos, produção de espermatozoides, testosterona, rato Wistar.

\begin{abstract}
Some compounds present in therapeutic plants may be responsible for the occurrence of adverse side effects. Coumarin and flavonoids are substances found in many plant species that showed antifertility activity in female rats and dogs, respectively. Mikania glomerata Spreng., Asteraceae, known as guaco in Brazil, is a plant largely used in folk medicine and its leaves are reported to have coumarin and flavonoids. This work analyzes the effect of chronic administration of $M$. glomerata on the reproductive system of male rats. Thirty-day-old Wistar rats were treated with $M$. glomerata hydroalcoholic extract at a dose of $3.3 \mathrm{~g} / \mathrm{kg}$ of body weight for ninety days. Body and organ weights, gamete concentration on the epididymis cauda, serum testosterone level and food consumption were evaluated. No significant alteration was observed in any of the variables analyzed, suggesting the absence of toxic action or antifertility activity of the M. glomerata hydroalcoholic extract.
\end{abstract}

Keywords: Mikania glomerata, reproductive organs, sperm production, testosterone level, Wistar rat.

\section{INTRODUCTION}

The genus Mikania contains more than four hundred species (King \& Robinson, 1987) Corrigir referência and is considered to be one of the largest genera of the Eupatorieae group. These species have been reported to have constituents such as sesquiterpene lactones, diterpenes, pimaradiene acids, steroids and coumarin (Sarg \& El-Dahmy, 1990; Cruz et al., 1996) and have extensively been used in folk medicine for their antiseptic, antitussive and expectorant properties (Cruz et al., 1996). Mikania glomerata Spreng., Asteraceae, popularly known in Brazil as guaco, is a member of this genus that, apart from being used to treat respiratory tract diseases (Neves 
\& Sá, 1991), has been employed as an anti-snake venom, analgesic and anti-inflammatory agent (Ruppelt et al., 1990). Phytochemical studies have revealed the presence of several substances in M. glomerata, including kaurenoic acid, cinnamoylgrandifloric acid, stigmaterol, flavonoids and coumarin (Oliveira et al., 1993; Vilegas et al., 1997 a, b; Martins et al., 2000; Cabral et al., 2001), a natural substance reported to be the main active compound from its leaves (Vilegas et al., 1997a).

The use of plants for therapeutic purposes has always been a common practice among the peoples of the world. In contemporary times special emphasis is being given to this subject in many ways, especially regarding pharmacological and industrial approaches concerning plants of medicinal interest. Despite the importance of this kind of work, close attention should be given to the indiscriminate use of such plants and the occurrence of adverse effects on the organism. The male reproductive system and its associated endocrine system can undergo a number of damaging alterations following exposures to a variety of chemical and physical agents that are capable of interfering with the integrity of the reproductive function. Among the chemical agents, there are many substances found in medicinal plants that are under current use by the population for treating various types of diseases. For instance, certain types of coumarin have been shown to have antifertility activity in mature female rats and to cause glomerulocapsular adhesion and segmental fusion in rats kidneys (Ulubelen et al., 1994). Flavonoids have been reported to have anti-snake activity (Nakagawa \& Nakanisha, 1982), but are also known to produce antiandrogenic activity and affect male fertility in dogs (Bhargava, 1989).

Taking into account the concern for reproductive hazards and the fact that at least two potential antifertility substances are present in M. glomerata, this study was aimed at investigating the effects of a hydroalcoholic extract of this plant on the reproductive organs and some vital organs, sperm production and serum testosterone level of Wistar rats submitted to sub chronic treatment.

\section{MATERIAL AND METHODS}

\section{Plant material}

Mikania glomerata Spreng., Asteraceae, was collected in the botanical garden of the Pharmacy and Biochemistry Faculty, Universidade Federal de Juiz de Fora (UFJF) and authenticated in the Herbarium Leopoldo Krieger, Department of Botany, (UFJF), where a voucher specimen registered under the number CESJ 34456 is deposited. The aerial parts were dried and powdered for the preparation of a hydroalcoholic extract. After extraction with $90 \%$ ethanol, the solvent was evaporated in a rotavapor and the residue was dissolved in distilled water.

\section{Animals and housing}

Immature male Wistar rats (Rattus norvegicus Berkenhout, 1769) of thirty days old and weighing around $70 \mathrm{~g}$ were obtained from the vivarium of UFJF, where they were born and bred. They were housed individually under standard laboratory conditions with a $12 \mathrm{~h}$ light/12 $\mathrm{h}$ dark photoperiod. They were fed on rat chow pellets and received water ad libitum. Animal care and the experimental protocol followed the principles and guidelines suggested by the Brazilian College of Animal Experimentation (COBEA) and were approved by the Ethical Committee of the Federal University of Juiz de Fora (UFJF) which follows the international rules (EEC Directive-86/609/ EEC) (Protocol number: 013/2004-CEA).

\section{Bioassay}

The animals were randomly divided into control and treated groups, containing twenty animals each. The rats from the treated group received, by gavage and once daily, M. glomerata hydroalcoholic extract of at a dose of $3.3 \mathrm{~g} / \mathrm{kg}$ of body weight, administered for $90 \mathrm{~d}$. The control group received $1 \mathrm{~mL}$ of distilled water following the same protocol as the treated group.

During the experiment, the animals were inspected twice daily for detection of clinical signs of toxicity, such as piloerection, and alterations in locomotor activity (Mason \& Kang, 1994). The animals were weighed before the beginning of treatment, once a week and at the end of treatment. Food consumption was monitored daily. On the ninety first day, the animals were killed by an overdose inhalation of anesthetic (halothane). Immediately after death, the following organs were dissected out and weighed: testes, left epididymis, seminal vesicle, prostate, liver, kidneys, lungs, brain and the pituitary gland. The left testis and epididymis were then fixed in Bouin for histological examination. The tissues were dehydrated in a graded series of ethanol, embedded in paraffin and sectioned at 3 $\mu \mathrm{m}$ thickness for routine haematoxylin and eosin staining, and light microscope examination (Humason, 1972).

Sperm were collected from the epididymal secretion of the right epididymis cauda. The secretion was placed in a $0.3 \mathrm{~mL}$ drop of saline extract and later diluted in distilled water. From this homogenate, a sample was taken and the number of sperm counted using a hemocytometer with improved double Neubauer ruling (Moraes, 1994).

To analyze the serum testosterone level, a blood sample was withdrawn by cardiac puncture from control $(n=10)$ and treated $(n=10)$ rats. The blood was collected between 8 am and $1 \mathrm{pm}$ and centrifuged at $17{ }^{\circ} \mathrm{C}, 250$ rpm for $15 \mathrm{~min}$ for the separation and extraction of $1 \mathrm{cc}$ of serum. The dosing of the circulating testosterone was carried out using the immunofluorimetry method (Hermes Pardini Laboratory, Belo Horizonte, Brazil). 


\section{Statistical analysis}

The Student's $t$ test was applied for statistical comparison of the differences in data between the test groups $(\alpha=0.05)$ and the results were expressed by mean and standard deviation (SD). The serum testosterone level was analyzed using the Wilcoxon-Mann-Whitney test ( $\alpha=$ 0.05) (Sokal \& Rohlt, 1996).

\section{RESULTS AND DISCUSSION}

Plants have served as a natural source of substances that may affect the development or normal functioning of the reproductive system (Rajasekaran et al., 1988; Bidwai et al., 1990; Hiremath et al., 1997; Montanari et al., 1998; Abdel-Magied et al., 2001). For instance, coumarin is known to have antifertility activity in female rats (Ulubelen et al., 1994) and flavonoids to produce antiandrogenic activities and to affect male dog fertility (Bhargava, 1989). Both substances have been reported to be among the active compounds of the aerial parts of Mikania glomerata Spreng., Asteraceae, (Vilegas et al., $1997 \mathrm{a}$, b; Martins et al., 2000) thus suggesting a possible toxic behavior of this plant on the reproductive system.

In this work, immature male rats were treated with M. glomerata hydroalcoholic extract at a dose level $(3.3 \mathrm{~g} /$ $\mathrm{kg}$ of body weight) that was six hundred times higher than the human dose for ninety consecutive days. The dose used was based on previous works in which the effect of $M$. glomerata extract administered during the spermatogenic cycle of rats and its dominant lethality in male rats were investigated (Sá et al., 2003, 2006). At the beginning of treatment the reproductive organs of the rats were not completely developed, but by the time the treatment was over, the animals were fully grown and sexually mature. The high dose and long-term administration of the extract did not seem to have caused any toxic effect in the rats as no death, no clinical signs of toxicity such as locomotor activity alterations and piloerection, and no significant body weight reduction (Figure 1) were detected. Daily food intake was not affected by the administration of the plant extract either (Figure 2). The treatment did not produce undesirable side effects on vital organs such as the liver, kidneys, lungs, brains and the pituitary gland, on the organs of the reproductive system, and on the accessory sex glands (Table 1), as evident by their weights which were not altered significantly. These results were similar to those obtained in male rats treated with $M$. glomerata hydroalcoholic extract at two lower dose levels (1.1 and $2.2 \mathrm{~g} / \mathrm{kg}$ of body weight) that were two hundred and four hundred times higher than the human dose, respectively (data not shown).

The pituitary gland plays a major role on the development and functioning of the male reproductive system by secreting follicle-stimulating hormone (FSH) and luteinizing hormone ( $\mathrm{LH}$ ) that act on the test is to produce sex steroid hormones and male gametes (Mahony \& Hodgen, 1995). Although some sort of damage would be expected to occur because the animals used were still undergoing sexual maturation during the experimental procedure, no androgenic or anti-androgenic effects were detected in the treated animals corroborating the normal functioning of the reproductive organs, including the androgen-dependent accessory sex glands. Serum testosterone concentration in the adult male rat was measured on the ninety first day and showed a large variation among the animals in both control and treated groups, which ranged from a low 0.70 $\mathrm{ng} / \mathrm{mL}$ to a high $19.3 \mathrm{ng} / \mathrm{mL}$. The values obtained were not statistically different between the control and treated animals (Control $(\mathbf{C})=4.20 \pm 5.00 \mathrm{ng} / \mathrm{mL}$ and Treated (T) $=6.13 \pm 5.80 \mathrm{ng} / \mathrm{mL})$ and were within the values reported in previous studies (Coyotupa et al., 1973; Pujol et al., 1976; Fahim et al., 1982; Viguier-Martinez et al., 1985; Linder et al., 1995; Sá et al., 2003).

A comprehensive assessment of the effects of chemicals on male reproductive functioning requires study of effects on spermatogenesis and the quality of spermatozoa produced (Blazak et al., 1985). Despite the high dose used and the long duration of treatment, the coumarin and flavonoids present in the M. glomerata extract were not toxic to the testis, the left epididymis, the prostate and the seminal vesicle. No impairment of the spermatogenic cycle was observed and the sperm concentration from the secretion of the right epididymis cauda did not differ significantly between the groups: (C) $=909.13 \pm 149.47 \times 10^{6} \mathrm{sperm} / \mathrm{mL}(\mathrm{mean} \pm \mathrm{SD})$ and (T) $=1018.88 \pm 201.54 \times 10^{6} \mathrm{sperm} / \mathrm{mL}$. The sperm morphology seemed unaffected by the treatment as the proportion of normal and abnormal spermatozoa was comparatively similar between the control and treated groups. Spermatozoa without head or tail and with coiled tail were the most common abnormalities present which also showed a similar concentration in both groups.

The histological examination revealed that there was no structural alteration in the seminiferous epithelium of the treated rats' testis (Figure 3) when compared to the controls. Similarly, the epididymis of control and treated rats (Figure 4) showed a normal epithelium lining and presence of spermatozoa in all segments (head, body and tail) of this organ.

In conclusion, the data showed in this work points to the absence of toxicity of the M. glomerata hydroalcoholic extract as a high dose and long-term treatment with this plant did not produce any toxic effect on important vital organs of the Wistar rat. The functioning of the reproductive system and its related endocrine system was not affected which resulted in normal androgen production and gamete secretion. 


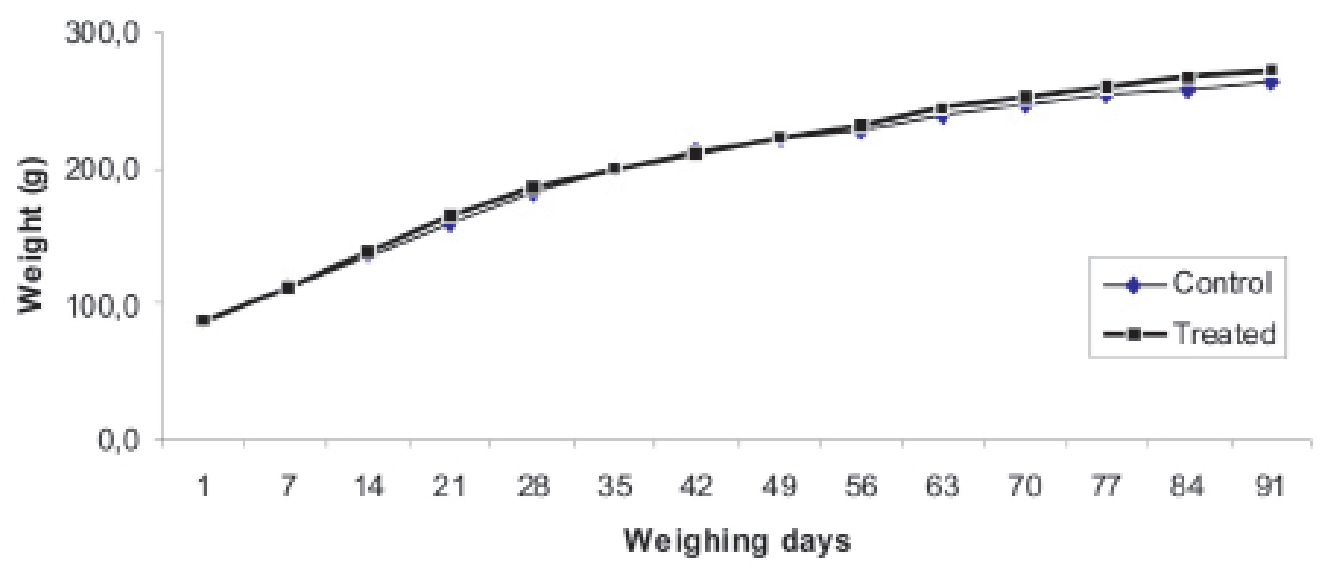

Figure 1. Body weight of control and Mikania glomerata extract treated Wistar rats ( $3.3 \mathrm{~g} / \mathrm{kg}$ of body weight) submitted to subchronic treatment, with exposure of ninety days and death on the ninety first day.

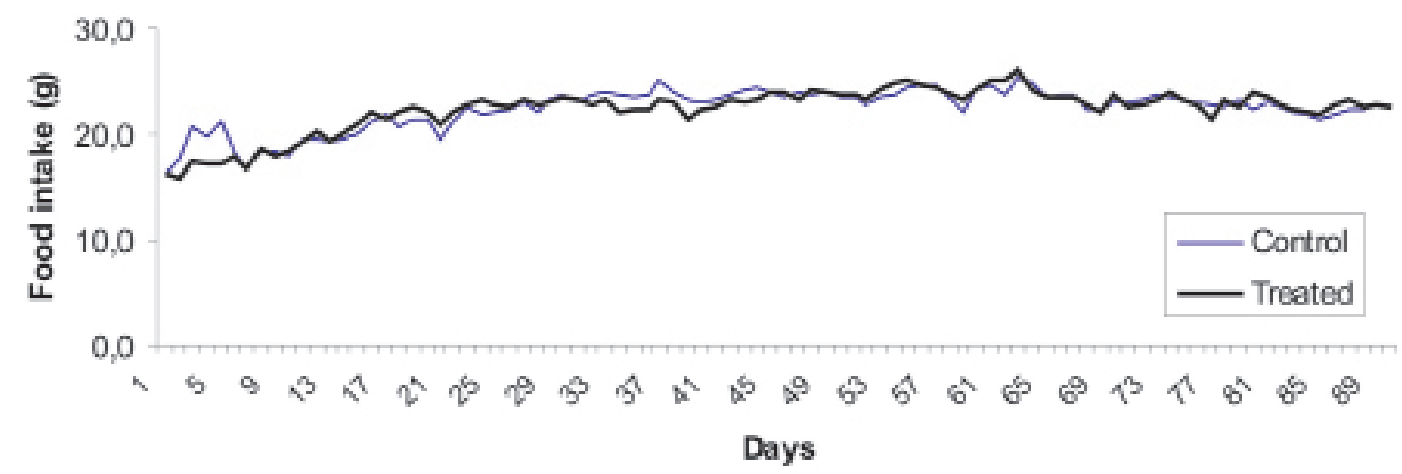

Figure 2. Daily food consumption of control and Mikania glomerata extract-treated Wistar rats (3.3 $\mathrm{g} / \mathrm{kg}$ of body weight) submitted to subchronic treatment, with exposure of ninety days and death on the ninety first day.

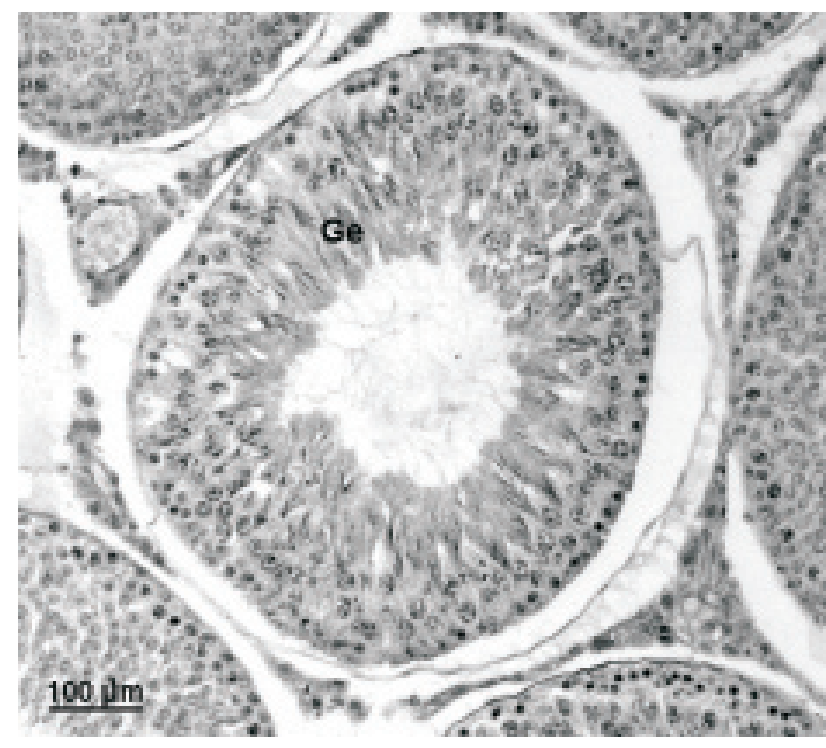

Figure 3. Cross section of the seminiferous tubule of $M$. glomerata extract-treated Wistar rats, showing the germinal epithelium $(\mathrm{Ge})$ with normal morphology.

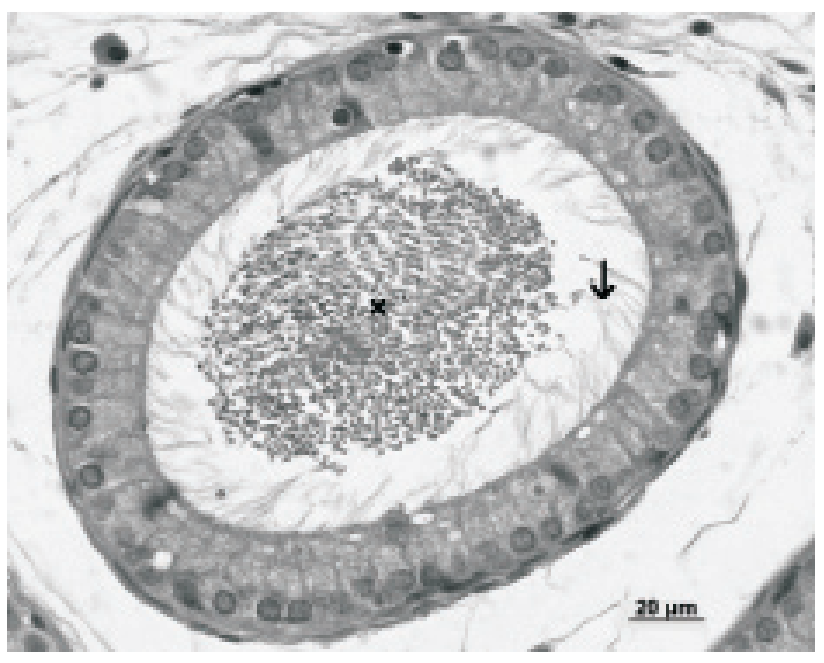

Figure 4. Cross section of the epididymis head of M. glomerata extract-treated Wistar rats, showing normal epithelium lining with sterocilia (arrow) and spermatozoa in the lumen (asterisk). Table 1. Organ weights of control and Mikania glomerata extract-treated Wistar rats $(3.3 \mathrm{~g} / \mathrm{kg}$ of body weight) submitted to subchronic treatment, with exposure of ninety days and death on the ninety first day. 
Table 1. Organ weights of control and Mikania glomerata extract-treated Wistar rats $(3.3 \mathrm{~g} / \mathrm{kg}$ of body weight) submitted to subchronic treatment, with exposure of ninety days and death on the ninety first day.

\begin{tabular}{lcc}
\hline \multirow{2}{*}{ Weight $(\mathrm{g})$} & \multicolumn{2}{c}{ Group } \\
\cline { 2 - 3 } & Control & Treated \\
\hline Brain & $1.11 \pm 0.07$ & $1.11 \pm 0.07$ \\
Pituitary (mg) & $7.08 \pm 1.00$ & $7.25 \pm 1.22$ \\
Liver & $9.54 \pm 1.98$ & $10.75 \pm 1.26$ \\
Lung & $1.37 \pm 0.23$ & $1.21 \pm 0.15$ \\
Right kidney & $0.94 \pm 0.16$ & $0.97 \pm 0.11$ \\
Left kidney & $0.94 \pm 0.16$ & $0.96 \pm 0.11$ \\
Right testicle & $1.31 \pm 0.06$ & $1.36 \pm 0.10$ \\
Left testicle & $1.27 \pm 0.08$ & $1.30 \pm 0.15$ \\
Left epididymis & $0.46 \pm 0.04$ & $0.46 \pm 0.05$ \\
Seminal vesicle & $0.27 \pm 0.06$ & $0.27 \pm 0.05$ \\
Prostate & $0.30 \pm 0.08$ & $0.31 \pm 0.06$ \\
\hline
\end{tabular}

Results expressed in mean \pm SD. $\mathrm{N}=12$.

\section{ACKNOWLEDGMENTS}

The authors are grateful to Fernanda Lima Lopes and Maycon de Moura Reporedo for technical support and to Ms Sharon Lloyd for reviewing the English version of this manuscript.

\section{REFERENCES}

Abdel-Magied EM, Abdel-Rahman HA, Harraz FM 2001. The effect of aqueous extract of Cynomorium coccineum and Withania somnifera on testicular development in immature Wistar rats. J Ethnopharmacol 75: 1-4.

Bhargava SK 1989. Antiandrogenic effects of a flavonoid rich fraction of Vitex negundo seeds: a histological and biochemical study in dogs. J Ethnopharmacol 27: 327339.

Bidwai PP, Wangoo D, Bhullar N 1990. Antispermatogenic action of Celastrus paniculatus seed extract in the rat with reversible changes in the liver. $J$ Ethnopharmacol 28: 293-303.

Blazak WF, Ernst TL, Stewart BE 1985. Potential indictors of reproductive toxicity: testicular sperm production and epididymal sperm number, transit time, and motility in Fischer 344 rats. Fund Appl Toxicol 5: 1097-1103.

Cabral LM, Dos Santos TC, Alhaique F 2001. Development of a profitable procedure for the extraction of 2-H-1benzopyran-2-one (coumarin) from Mikania glomerata. Drug Dev Ind Pharm 27: 103-106.

Coyotupa J, Parlow AF, Kovacic N 1973. Serum testosterone and dihydrotestosterone levels following orchiectomy in the adult rat. Endocrinology 92: 1579-1581.

Cruz FG, Roque NF, Giesbrecht AM, Davino SC 1996. Antibiotic activity of diterpenes from Mikania triangularis.
Fitoterapia 67: 189-190.

Fahim MS, Fahim Z, Harman JM, Clevenger TE, Mullins W, Hafez SE 1982. Effect of Panax ginseng on testosterone level and prostate in male rats. Arch Andrology 8: 261263

Hiremath SP, Badami S, Swamy HKS, Patil SB, Londonkar RL 1997. Antiandrogenic effect of Striga orobanchioides. $J$ Ethnopharmacol 56: 55-60.

Humason GL 1972. Animal Tissue Techniques (3rd edn). San Francisco: WH Freeman.

King RM, Robinson H 1987. The genera of the Eupatorieae (Asteraceae). Monogr Syst Bot 22: 1-581.

Linder RE, Klinefelter GR, Strader LF, Narotsky MG, Suarez JD, Roberts NL, Perreault SD 1995. Dibromoacetic acid affects reproductive competence and sperm quality in the male rat. Fund Appl Toxicol 28: 9-17.

Mahony MC, Hodgen GD 1995. Toxic effects on the hypothalamus-anterior pituitary-gonadal axis, control on the male and female reproductive system, and related issues. In: Witorsch RJ (Ed). Reproductive Toxicology. 2 ed. New York: Raven Press, p. 195-213.

Martins ER, Castro DM, Castellani DC, Dias JE 2000. Plantas Medicinais. Viçosa: Editora UFV.

Mason JM, Kang YJ 1994. Test methods for assessing female reproductive and developmental toxicology. In: Hayes AW (Ed). Principle and Methods of Toxicology. 3 ed. New York: Raven Press, p. 980-1037.

Montanari T, Carvalho JE, Dolder H 1998. Antispermatogenic effect of Achillea millefolium L. in mice. Contraception 58: 309-313.

Moraes GES 1994. Espermocitograma. Porto Alegre: Editora Médica Missau.

Nakagawa M, Nakanisha K 1982. Structures of cabenegrin I and II, potent anti-snake venoms. Tetrahedron Lett 23: 38553858.

Neves LJ, Sá MFA 1991. Contribuição ao estudo das plantas medicinais Mikania glomerata Spreng. Rev Bras Farmacogn 72: 42-47.

Oliveira F, Saito ML, Garcia LO 1993. Caracterização cromatográfica em camada delgada do extrato fluído de guaco Mikania glomerata Sprengel. Lecta 11: 43-56.

Pujol A, Francis B, Louvet J-P, Boulard C 1976. Testosterone and dihydrotestosterone concentrations in plasma, epididymal tissues, and seminal fluid of adult rats. Endocrinology 98 : 111-113.

Rajasekaran M, Bapna JS, Lakshmana S, Ramachandrannair AG, Veliath AJ, Panchanadam M 1988. Antifertility effect in male rats of oleanolic acid, a triterpene from Eugenia jambolana flowers. J Ethnopharmacol 24: 115-121.

Ruppelt BM, Pereira EFR, Gonçalves LC, Pereira NA 1990. Abordagem farmacológica de plantas recomendadas na medicina folclórica como antiofídicas. I-Atividades analgésica e antinflamatória. Rev Bras Farmacogn 71: 54-56.

Sá RCS, Leite MN, Reboredo MM, Almeida RN 2003. Evaluation of long-term exposure to Mikania glomerata (Sprengel) 
extract on male Wistar rats' reproductive organs, sperm production and testosterone level. Contraception 67: 327-331.

Sá RCS, Leite MN, Peters VM, Guerra MO, Almeida RN 2006. Absence of mutagenic effect of Mikania glomerata hydroalcoholic extrac on adult Wistar rats in vivo. Braz Arch Biol Technol 49: 599-604.

Sarg TM, El-Dahmy S 1990. A further new ent-labdane from Mikania alvimii. Fitoterapia 61: 160-161.

Sokal RR, Rohlf FJ 1996. Biometry. The Principles and Practice of Statistics in Biological Research. New York: WH Freeman and Co.

Ulubelen A, Ertugrul L, Birman H, Yigit R, Erseven G, Olgac V 1994. Antifertility effects of some coumarins isolated from Ruta chalepensis and R. chalepensis var. latifolia in rodents. Phytother Res 8: 233-236.

Viguier-Martinez M-C, De Reviers M-TH, Perreau C 1985. Effects of flutamide or of supplementation with testosterone in prepubertal male rats prenatally treated with bulsufan. Acta Endocrinol-Cop 109: 550-557.

Vilegas JHY, Marchi E, Lanças FM 1997a. Extraction of lowpolarity compounds (with emphasis on coumarin and kaurenoic acid) from Mikania glomerata ("guaco") leaves. Phytochem Analysis 8: 266-270.

Vilegas JHY, Marchi E, Lanças FM 1997b. Determination of coumarin and kaurenoic acid in Mikania glomerata ("guaco") leaves by high resolution gas chromatography. Phytochem Analysis 8: 74-77. 